\title{
Assessment of the Development of Professional Skills in University Students: Sustainability and Serious Games
}

\author{
Noemi Peña Miguel ${ }^{1, * \mathbb{D}}$, Javier Corral Lage ${ }^{1}$ and Ana Mata Galindez ${ }^{2}$ \\ 1 Financial Economics I, University of the Basque Country (UPV/EHU), 48015 Bilbao, Spain; \\ javier.corral@ehu.eus \\ 2 Corporate Social Responsibility, Camara Bilbao Business School, 48008 Bilbao, Spain; \\ ana.mata@camarabilbaoubs.com \\ * Correspondence: noemi.pena@ehu.eus
}

Received: 31 December 2019; Accepted: 26 January 2020; Published: 31 January 2020

\begin{abstract}
In this study, we analyze the development of key professional skills for sustainability (KPSS) in university students using serious games (SG) from a sustainability perspective. Sustainable Development Goals (SDGs) were set by the United Nations' 2030 Agenda for Sustainable Development. Universities are strategic agents in the transformation process towards sustainability. Thus, universities should be committed to promoting such skills in their students through sustainable curricula by implementing active methodologies and using SG for that purpose. KPSS are essential for the development of future graduates. The aim of this study is to determine what KPSS have to be developed through the SG "The Island", in order to improve the degree of satisfaction towards the incorporation of a sustainable curriculum among the students. The data were obtained using a questionnaire and then analyzed using linear regression models, with their inferences estimated through a goodness of fit test and ANOVA. The first results indicated that implementation of the SG promoted a strengthening of the students' sustainable curriculum through the development of related skills. It was concluded that the key to success in education for sustainable development is to improve the development of strategic thinking, collaborative thinking, and self-awareness, in addition to encouraging systemic, critical, and problem-solving thinking.
\end{abstract}

Keywords: active learning; professional skills; civic education; higher education, serious games; critical thinking; sustainability; EDS competences

\section{Introduction and State of Play}

\subsection{Introduction}

The concept of sustainability emerged in the 1960s in response to concerns about environmental degradation resulting from poor resource management. As the environment became increasingly important as a world issue, sustainability was adopted as a common political goal. In 1960, the Organization for Economic Cooperation and Development (OECD) was created to promote policies that would achieve 'the highest sustainable economic growth and employment in Member countries in order to stimulate employment and increase living standards' [1].

Sustainability policy refers to a set of ideas or plans about what to do in particular situations, which have been agreed upon officially by a group of people, a business organization, a government, or a political party. Sustainability policy is important at the institutional, corporate, regional, state, and alliance levels. Policy can be locally, nationally, or internationally oriented and can address issues such as sustainable development, climate change, air, water, waste, and health [2]. 
In 1980, the World Conservation Strategy was released by the International Union for the Conservation of Nature. This strategy defines the 'main agents of habitat destruction and environmental degradation as poverty, population pressure, social inequity and the terms of trade'. Sustainable development was defined as the maintenance of essential ecological processes and life support systems, including those of humans. It emphasizes the evolution of human society from a responsible economic point of view, in accordance with environmental and natural processes [2].

During the past century, and the early decades of the new one, important steps have been taken to support sustainable development. The most recent effort, The 2030 Agenda for Sustainable Development, prepared by the General Assembly of the United Nations, established Sustainable Development Goals (SDGs), which indicate the most important development challenges for humanity, in order to ensure a sustainable, peaceful, prosperous, and equitable life for all individuals, not only in the present but also in the future. These objectives consider a series of social needs, including education, health, social protection, and job opportunities, in addition to climate change and environmental protection. To achieve a more sustainable world and meet all the goals set in the SDGs, individuals should become agents of change, acquiring knowledge, skills, values, and becoming engaged in behaviors that empower them to contribute to sustainable development through key professional skills for sustainability (KPSS) [3].

Universities, which are understood as essential agents in the transformation process towards sustainability, are committed to promoting these KPSS in their students. Therefore, including the promotion of a sustainable curriculum in university curricula, the implementation of active methodologies in the classrooms, and the use of new information and communication technologies (ICTs)—such as business simulators or 'serious games' (SG) - are mechanisms targeted at training the students in KPSS to achieve SDGs and to ensure that they will acquire the necessary theoretical and practical knowledge to promote sustainable development.

KPSS represent skills that are necessary for all future graduates and can be understood as transversal, multifunctional, and context-independent. They do not replace the specific competencies needed to act successfully in some situations and contexts, but they do contextualize them and give them a broader scope $[4,5]$. Students in Economics and Business are trained for decision-making in organizations. In the near future, these students will have to combine their decisions with the achievement of SDGs, and for this, they will need to be nurtured by human resources, where KPSS have been developed through sustainable curricula.

The purpose of this article is to assess the KPSS that should be developed through a Serious Game (SG) called "the Island" to improve the degree of student satisfaction with the incorporation of sustainable curricula. We have contributed to the literature by assessing which of the essential skills for sustainability proposed by UNESCO can be developed by students after engaging in SG.

Indeed, there is no consensus about the influence of serious games on the sustainability knowledge of students, mainly because there is no overall consensus. The results of studies related to the evolution of SG for sustainability are inconclusive. Some researchers did not find statistically specific differences involving the use of SG. However, [6] found a positive relationship between SG and sustainability.

Our goal is to assess, through linear regression models (with inferences estimated through a goodness of fit test and ANOVA) the potential of SG as e-learning tools for promoting KPSS in the classroom.

\subsection{State of Play}

\subsubsection{Education for Sustainable Development}

Education for Sustainable Development (ESD) is a holistic and transformative educational approach [7]. It addresses the content and results of active learning, pedagogy, and the learning environment, in order to evolve from teaching to learning and to transition from an instructional to a transformative pedagogical dimension [8]. In this way, the students take action through collaborative, 
participatory, and self-directed learning. By means of civic education, students are empowered and start making conscious decisions and acting responsibly, without losing sight of the economic, social, and environmentally sustainable development for tomorrow $[9,10]$.

Between 2005 and 2014, the United Nations began promoting changes in students' knowledge, values, and behaviors, with the purpose of achieving a more sustainable society. This project was called the United Nations Decade of Education for Sustainable Development [11].

Throughout the last few decades, the international recognition of Education for Sustainable Development (ESD) as a key approach to achieving sustainable development has been increasing steadily and was referenced in the three summits on sustainable development: the 1992 United Nations Conference on Environment and Development (UNCED) in Rio de Janeiro [12], the 2002 World Summit on Sustainable Development (WSSD) in Johannesburg [13], and the 2012 United Nations Conference on Sustainable Development (UNCSD) in Rio de Janeiro [14]. In addition, it is worth mentioning that Article 12 of the 2016 Paris Agreement acknowledges the importance of education in achieving a sustainable planet [10]. ESD is conceived of as education that occurs throughout life. This way, it develops in both formal and informal institutions and extends from kindergarten to university [15].

If we focus on university education, during the Ibero-American Conference on SDGs, [16] emphasized the transformative role of universities, which are perceived as an ecosystem that educates, transmits knowledge and skills, investigates, innovates, and seeks solutions. These processes are based on principles like education for peace and social justice.

When we discuss sustainable development and consider what it has entailed and what it will entail, a profound transformation is required, not only in our beliefs and perceptions, but also in the current behaviors of young individuals [17-19]. Learning to do and to be requires total involvement in the change and transformation of our society. Thus, students should become active agents of change. We should note that, from this perspective, education is crucial to achieving SDGs $[10,20]$.

Bokova, Director-General of UNESCO, indicated that "A fundamental change is needed in the way we think about the role of education in world development, because it has a catalytic effect on the well-being of individuals and the future of our planet. [...] Now, more than ever, education is responsible for taking into consideration the challenges and aspirations of the $21^{\text {st }}$ century, as well as promoting the right types of KPSS that will lead to sustainable and inclusive growth, and to a peaceful life for all individuals" [10].

ESD allows students to face ethical problems in which they have to decide what standards and codes society should develop to frame human actions for greater economic well-being while maintaining the natural environment. Thus, students will have to assess and develop a code of ethics for sustainability when deciding which resources to use for economic, social, and environmental challenges, both in the classroom and in real life [21].

Therefore, a strand of work has also emphasized the need for research in the development of professional skills in education. The career profile of every individual should not be based solely on functions but on skills, since a professional with a more open, versatile character and with a greater capacity for flexibility and adaptation to specific situations is required, especially in the financial and insurance sector [22]. The attainment of these professional skills will help to maximize the effectiveness of a company $[23,24]$.

The majority of individuals acquire highly specific skills during their academic training, depending on the degree studied. However, at present, companies also demand training in transversal or generic skills that are suitable for professional performance. Moreover, companies are presently seeking out people with KPSS. For this reason, this paper attempts to contribute to the literature by assessing the development of KPSS through Serious Games (SG). That is, we seek to determine if the use of the Serious Game called « The Island » can promote a strengthening of the students" sustainable curriculum for developing KPSS. 


\subsubsection{Sustainable Development Goals}

On 25th September 2015, the United Nations General Assembly adopted the 2030 Agenda for Sustainable Development. This Agenda resulted from work performed for more than three years after the United Nations Conference on Environment and Development, held in Rio de Janeiro, Brazil, in June 2012. Member States were involved, with the participation of millions of individuals in a participatory citizenship process.

The universality and the indivisibility of the 2030 Agenda are crucial aspects of its development. The signatory countries committed to aligning their individual commitments with the universal, transformative, and inclusive objectives of the 2030 Agenda [10]. The purpose of the 17 objectives with their 169 goals is to ensure a sustainable, peaceful, equitable, and prosperous life for all inhabitants of our planet, both now and in the future. We are currently facing global challenges that affect everyone (i.e., the survival of our species). Environmental limits and thresholds of natural resources should thus be established, and poverty eradication actions should be aligned with economic development strategies, without forgetting social needs and climate change [10].

The spirit of the 2030 Agenda is based on 17 Sustainable Development Goals, which summarize the actions to be performed over the next few years by public administrations, private companies, non-profit entities, universities, and citizens in general (Figure 1). In order to achieve these objectives, the different participants (e.g., private companies, public administrations, civil society, and every citizen) must meet their commitments [25]. If we focus on the specific field of action of higher education, we can observe that universities play an important role in multi-stakeholder alliances, in addition to leading by example. Universities are, therefore, pioneers with respect to the SDG proposals [16,26].

\begin{tabular}{|c|c|c|}
\hline 1 & END OF POVERTY & End poverty, in all its forms, throughout the world. \\
\hline 2 & ZERO HUNGER & $\begin{array}{l}\text { End hunger, achieve food security, improve nutrition, and } \\
\text { promote sustainable agriculture. }\end{array}$ \\
\hline 3 & HEALTH AND WELLNESS & $\begin{array}{l}\text { Ensure a healthy life and promote well-being for all individuals at } \\
\text { all ages. }\end{array}$ \\
\hline 4 & QUALITY EDUCATION & $\begin{array}{l}\text { Ensure inclusive, equitable and quality education, and promote } \\
\text { lifelong learning opportunities for all individuals. }\end{array}$ \\
\hline 5 & GENDER EQUALITY & Achieve gender equality and empower all women and girls. \\
\hline 6 & $\begin{array}{l}\text { CLEAN WATER AND } \\
\text { SANITATION }\end{array}$ & $\begin{array}{l}\text { Ensure water availability and its sustainable management, and } \\
\text { sanitation for all individuals. }\end{array}$ \\
\hline 7 & $\begin{array}{l}\text { AFFORDABLE AND NON- } \\
\text { POLLUTING ENERGY }\end{array}$ & $\begin{array}{l}\text { Ensure access to affordable, safe, sustainable, and modern energy } \\
\text { for all individuals. }\end{array}$ \\
\hline 8 & $\begin{array}{l}\text { DECENT WORK AND } \\
\text { ECONOMIC GROWTH }\end{array}$ & $\begin{array}{l}\text { Promote sustained, inclusive, and sustainable economic growth, } \\
\text { full and productive employment, and decent work for all } \\
\text { individuals. }\end{array}$ \\
\hline 9 & $\begin{array}{l}\text { INDUSTRY, INNOVATION, } \\
\text { AND INFRASTRUCTURES }\end{array}$ & $\begin{array}{l}\text { Build resilient infrastructures, promote inclusive and sustainable } \\
\text { industrialisation, and foster innovation. }\end{array}$ \\
\hline 10 & REDUCTION OF INEQUALITY & Reduce inequality in and between countries. \\
\hline 11 & $\begin{array}{l}\text { SUSTAINABLE CITIES AND } \\
\text { COMMUNITIES }\end{array}$ & $\begin{array}{l}\text { Make cities and human settlements inclusive, safe, resilient, and } \\
\text { sustainable. }\end{array}$ \\
\hline 12 & $\begin{array}{l}\text { RESPONSIBLE PRODUCTION } \\
\text { AND CONSUMPTION }\end{array}$ & Ensure sustainable consumption and production modalities. \\
\hline 13 & ACTION FOR THE CLIMATE & Take urgent measures to combat climate change and its effects. \\
\hline 14 & UNDERWATER LIFE & $\begin{array}{l}\text { Preserve and use the oceans, seas, and marine resources in a } \\
\text { sustainable manner to ensure sustainable development. }\end{array}$ \\
\hline 15 & $\begin{array}{l}\text { LIFE OF TERRESTRIAL } \\
\text { ECOSYSTEMS }\end{array}$ & $\begin{array}{l}\text { Protect, restore, and promote the sustainable use of terrestrial } \\
\text { ecosystems. }\end{array}$ \\
\hline 16 & $\begin{array}{l}\text { PEACE, JUSTICE, AND SOLID } \\
\text { INSTITUTIONS }\end{array}$ & $\begin{array}{l}\text { Promote equitable, peaceful, and inclusive societies for sustainable } \\
\text { development. }\end{array}$ \\
\hline 17 & $\begin{array}{l}\text { ALLIANCES TO ACHIEVE } \\
\text { OBJECTIVES }\end{array}$ & $\begin{array}{l}\text { Strengthen the means of implementation and revitalise the global } \\
\text { partnership for sustainable development. }\end{array}$ \\
\hline
\end{tabular}

Figure 1. Sustainable Development Goals. Source: adapted from [25].

Universities can promote research activities that entail the subsequent transfer of knowledge and thereby sensitize citizens to these SDGs. The ways through which these goals can be achieved should 
be set creatively by each institution. For example, the Conference of Rectors of Spanish Universities (CRUE) faces the challenge of raising awareness among its students [27].

The 2030 Agenda impacts universities because it represents: (a) An internal transformation that leads to rethinking 'what', 'how', and 'what for' the universities teach; (b) an external transformation due to the repositioning of universities within society; and (c) university contexts that articulate the participants' needs and generate inclusive alliances [28-30].

\subsubsection{The KPSS for Sustainable Development Among University Students}

Although international institutions, such as the United Nations in 2007, have promoted the implementation of the principles for Responsible Management Education (PRME) as a platform to raise the profile of sustainability in schools around the world, and to equip today's business students with the ability to deliver change tomorrow, recent studies promoted by UNESCO in 2017 introduced challenges with greater degrees of complexity and uncertainty than those presented in the past. For this reason, we have to consider the KPSS promoted by UNESCO.

As we have commented, it is essential to introduce environmental and social perspectives in the curricula of future graduates-not only oriented towards professional development but also for personal life. This process is known as 'sustainable curriculum' [31] and is an evolution of the concept of 'curricular environmentalisation' [32], with the aim of addressing sustainable aspects as well as environmental concepts, unlike the previous concept.

New generations face greater individualization, social diversity, degradation, and social and environmental vulnerability, among other factors. Facing these issues requires creative and autonomous behavior, in addition to having truthful, clear, and concise information on all the variables that can affect the resolution of the problems and challenges that may arise.

Therefore, university students should have the necessary skills to collaborate and perform with the goal of obtaining positive changes in society and the surrounding environment [25] (i.e., becoming truly sustainable citizens) [33,34].

The roles of the university, as a vehicle for sustainable development among students, society, and other entities are fundamental [35]. Educating via sustainability in the curricula of university students implies developing a series of KPSS. The implementation and achievement of these skills will allow students to face the future challenges that the current globalized labor market, with exponential technological growth, will demand.

Thus, the adoption of these competences will be crucial if students are to be involved responsibly and constructively in the future of a sustainable economic, social, political, and environmental environment [3,24,36-39] (Figure 2).

These KPSS describe the specific attributes that students need for action and autonomy in different situations and complex contexts, including not only motivational but also cognitive, affective, and volitional elements [10]. KPSS should be understood as competencies that do not replace other competencies [4], such as the competencies of teamwork, effective communication, and data analysis, among others [40,41]. However, students should understand them and acquire a wider scope of knowledge [5]. In addition, to support the achievement of SDG targets, KPSS favor achievement in a more effective manner when various skills are interlinked [42].

The essential KPSS are those acquired through action, supported by the concepts of experience and reflection-KPSS are not taught but developed throughout study [5,25]. These skills, proposed by UNESCO [25], have been defined as crucial for the progress of sustainability $[3,24,43]$ 


\begin{tabular}{|c|c|}
\hline $\begin{array}{l}\text { SYSTEMIC THINKING } \\
\text { SKILL }\end{array}$ & $\begin{array}{l}\text { Students should be able to: (a) recognize and understand the } \\
\text { relationships that originate in society; (b) analyse complex and } \\
\text { disparate systems; (c) understand how these systems are integrated } \\
\text { within various domains and scales; and (d) fight against risk and } \\
\text { uncertainty. }\end{array}$ \\
\hline ANTICIPATION SKILL & $\begin{array}{l}\text { Students should have the ability to: (a) understand, analyse, and } \\
\text { evaluate different future scenarios, differentiating between possible, } \\
\text { probable, and desirable outcomes; (b) create their own perspectives } \\
\text { of what will happen in the future; (c) be cautious; (d) evaluate the } \\
\text { consequences of the actions they take; and (e) deal with the resulting } \\
\text { risks and changes. }\end{array}$ \\
\hline REGULATORY SKILL & $\begin{array}{l}\text { Future graduates should acquire the necessary skills to understand } \\
\text { and reflect on the norms and values that underlie their own actions. }\end{array}$ \\
\hline STRATEGIC SKILL & $\begin{array}{l}\text { Universities should encourage their students to collectively develop } \\
\text { and implement innovative actions that promote sustainable } \\
\text { development. }\end{array}$ \\
\hline $\begin{array}{l}\text { COLLABORATIVE } \\
\text { SKILL }\end{array}$ & $\begin{array}{l}\text { Students should learn from each other and understand and respect } \\
\text { the needs, perspectives, and actions of others, through empathy and } \\
\text { empathic leadership, addressing group conflicts and facilitating } \\
\text { problem solving in a collaborative and participatory manner. }\end{array}$ \\
\hline $\begin{array}{l}\text { CRITICAL THINKING } \\
\text { SKILL }\end{array}$ & $\begin{array}{l}\text { All students should question the norms, practices, and opinions that } \\
\text { surround them. In addition, they should reflect on the values, } \\
\text { perceptions, and, especially, their own actions, adopting a stance } \\
\text { based on a discourse focused on sustainability. }\end{array}$ \\
\hline $\begin{array}{l}\text { SELF-AWARENESS } \\
\text { SKILL }\end{array}$ & $\begin{array}{l}\text { Reflecting on the role that each future graduate will play in the } \\
\text { community and society is essential, as well as constantly evaluating } \\
\text { and promoting the actions that one performs, dealing with personal } \\
\text { feelings and desires. }\end{array}$ \\
\hline $\begin{array}{l}\text { INTEGRATED } \\
\text { PROBLEM-SOLVING } \\
\text { SKILL }\end{array}$ & $\begin{array}{l}\text { Students should learn to apply different problem-solving } \\
\text { frameworks to complex sustainable development problems and } \\
\text { devise equitable solutions that foster sustainable development by } \\
\text { integrating the other essential skills described above. }\end{array}$ \\
\hline
\end{tabular}

Figure 2. Key Professional Skills for Sustainable Development. Source: adapted from [25].

1.2.4. The Development of ESD through the Serious Game Known as "The Island"

The use of ICTs to promote active learning processes in higher education represents an improvement in the education process that allows teachers to promote new skills among students [44]. In the case of ESD, using SG as an e-learning tool can help implement the KPSS mentioned above in a more positive way [45-47].

'The Island' is the name of a serious game, in which students, in a given time-space domain, must make economic, social, and environmental decisions that allow them to effectively and efficiently govern a defined territory. In this way, while always keeping in mind the optimal achievement of the most possible SDGs, the students should collectively decide what actions should be taken and how and when they will be implemented in The Island to satisfy the citizens and avoid negative ecological impacts within the available budget.

The players are the mayors of the island, and their aim is to maximize the welfare of the inhabitants (the best use of natural resources, $R \& D$, and infrastructures). The students must manage the economy of the island to achieve the most sustainable balance. On this island, users have access to different sources of non-renewable energy, such as oil, natural gas, and uranium. They also have renewable energy sources, including water, the sun, and the wind. Moreover, since they live on an island, they must properly manage the available space. 
The aim of the students is to maximize the use of the resources available. The strategies implemented must consider the relevant framework of limitations, like in the real public management of resources (i.e., a budget comprising income and expenditures and possible new problems caused by the decisions made and the space involved).

This serious game helps students develop KPSS. Through the simulator, the students observe and value the various future scenarios that arise in the game. In addition, the students must determine and perceive the relationships between the decisions to be taken and the citizens, using different problem-solving frameworks in the face of the different situations outlined by the serious game. Likewise, students are offered the possibility to question their own practices and opinions or those of others, reaching conscious decisions and acting responsibly from economic, social, and environmental perspectives (Triple Bottom Linen).

\section{Materials and Methods}

\subsection{Descriptive Data}

In our eagerness to develop as key agents in the sustainable development transformation processes, we are committed to promoting these KPSS among students. Training future graduates in KPSS that allow them to achieve SDGs and develop the theoretical and practical knowledge necessary for their future work and personal lives is a top priority for both institutions. Therefore, using business simulators or SG through active methodologies in the classroom will help students include KPSS that can be useful in the labor market and in their personal lives.

However, implementing new education systems does not mean that students will acquire every skill demanded in the 2030 Agenda. The present work uses the methodological and quantitative tool of a questionnaire, which allows a social phenomenon to be studied as a dynamic process within its real context. For the elaboration of the questionnaire, different studies related to the analysis of competencies among students of education were taken into account [24,48,49].

A questionnaire composed of dichotomous questions and a Likert scale from 1 to 5 was given to students enrolled during the 2017/2018 academic year in the last year of their degree at the University Business School (UBS), in the Master's Degree in Account Auditing and Higher Accounting (MACS) program, or in the Master's Degree in Actuarial Sciences and Finance (MCAF) program at the Faculty of Economics and Business (FEE). (see Appendices A and B in Appendix A) The data were taken during the last quarter of 2017 and the first quarter of 2018 from the students at the educational centers where the survey was carried out. The selection of this sample is justified due to the proximity of the students to the labor force. On the one hand, students in the only two professional masters programs with activity reserves in the faculty of economics and business were chosen. On the other hand, students with a business management degree were selected because in the near future they will have to make decisions from the perspective of the triple bottom line.

The sample size was determined to achieve a maximum margin of error less than 0.05 points, in this case $\pm 5 \%$ with a $95 \%$ confidence level $(z=1.96$, for $e=0.05)$ for 456 students in the MCAF and MACS programs or fourth grade students in the USB (defined as finite).

$$
\mathrm{n}=\frac{\mathrm{N}}{1+\frac{\mathrm{e}^{2}(\mathrm{~N}-1)}{\mathrm{z}^{2} \mathrm{pq}}}
$$

Thus, the sample amounts to 208 students. Based on the answers considered to be valid, the final number of surveys was 88 . This figure is considered representative, since the students provided a $42.30 \%$ correct response rate relative to the sample size.

The questionnaire was taken by 88 students ( 50 women and 38 men) in the third year of their Degree in Business Marketing Management at the UBS (69 students), in the MACS (12 students), and in the MCAF (seven students), all from the FEE. 
The data were collected based on the courses related to the Accounting and Financial Information management specialty, as well as those related to KPSS and Corporate Social Responsibility. Given that the present study was focused on sustainable development, the respondents were asked to note the number of courses in which they had worked with SG (N_COUR_SG) and the number of courses in which they had dealt with issues related to sustainable development (N_COUR_SUST) (Tables 1 and 2).

Table 1. Descriptive statistics: Sample frequencies.

\begin{tabular}{cccccc}
\hline & & Frequency & Percentage & $\begin{array}{c}\text { Valid } \\
\text { Percentage }\end{array}$ & $\begin{array}{c}\text { Cumulative } \\
\text { Percentage }\end{array}$ \\
\hline \multirow{2}{*}{ SEX } & MAN & 38 & 43.2 & 43.2 & 43.2 \\
& WOMAN & 50 & 56.8 & 56.8 & 100 \\
& Total & 88 & 100 & 100 & 78.4 \\
UNDERGRADUATE/MASTER'S & CUBS & 69 & 78.4 & 78.4 & 91.9 \\
DAAHA & 12 & 13.5 & 13.5 & 100 \\
& MAFS & 7 & 8.1 & 8.1 & 27.3 \\
& Total & 88 & 100 & 100 & 86.4 \\
N_COUR_SG & 0 & 24 & 27.3 & 27.3 & 95.5 \\
& 1 & 52 & 59.1 & 59.1 & 100 \\
& 2 & 8 & 9.1 & 9.1 & 2.3 \\
& 2 & 4 & 4.5 & 4.5 & 45.5 \\
& Total & 88 & 100 & 100 & 81.8 \\
& 0 & 2 & 2.3 & 2.3 & 95.5 \\
& 1 & 38 & 43.2 & 43.2 & 100 \\
\hline
\end{tabular}

Note. N_COUR_SG = number of courses using Serious Games; N_COUR_SUST = number of courses addressing sustainable development. Source: prepared by the authors.

Table 2. Descriptive statistics: sample statistics.

\begin{tabular}{ccccccc}
\hline & & SEX & WORK & VOLUNTEERING & N_COUR_SG & N_COUR_SUST \\
\hline \multirow{2}{*}{$\mathrm{N}$} & Valid & 88 & 88 & 88 & 88 & 88 \\
& Lost & 0 & 0 & 0 & 0 & 0 \\
& Mean & 1.57 & 1.80 & 1.84 & 0.91 & 1.75 \\
Median & 2.00 & 2.00 & 2,00 & 1.00 & 2.00 \\
Mode & 2 & 2 & 2 & 1 & 1 \\
Standard deviation & 0.498 & 0.406 & 0.368 & 0.737 & 0.887 \\
Variance & 0.248 & 0.165 & 0.135 & 0.543 & 0.787 \\
\hline
\end{tabular}

Source: prepared by the authors.

Specifically, we assessed the relationship and the degree of association between the overall satisfaction with the use of the serious game known as "The Island" «Ch» to favor the development of sustainable curriculum «SAT_GEN», based on their degree of perception about the improvement of each KPSS through the application of The Island.

To assess all explanatory or dependent variables, we used a 5-point Likert scale ( 1 = very low; $2=$ low; $3=$ medium; $4=$ high; and $5=$ very high). These variables were:

STS $=$ Systemic thinking skill.

AS = Anticipation skill.

NS = Normative skill.

SS = Strategic skill.

$\mathrm{CS}=$ Collaborative skill.

CTS = Critical thinking skill.

SAS = Self-awareness skill. 
PSS = Integrated problem-solving skill.

The multiple linear regression model resulted in:

$$
\text { SAT_GEN }=\alpha+\sum_{h=1}^{8} \beta_{h} \cdot C_{h}
$$

where:

$\alpha$ : A constant.

$\beta_{h}$ : The partial relationship between each $h$ th explanatory variable and the explained variable.

$C_{h}$ : The $h$ th explanatory variable.

\subsection{Data Analysis}

We used the SPSS Statistics 24 software to perform a stepwise selection of the variables in order to carry out a multiple linear regression analysis. The purpose of this analysis was to find, among all the possible explanatory variables "Ch», those that best explained the degree of satisfaction of the independent variable «SAT_GEN», without any of them being a linear combination of the remaining variables.

This way, we determined the KPSS that influenced the degree of «SAT_GEN», based on their development through the application of The Island:

H0: The KPSS «Ch» does not affect the degree of «SAT_GEN».

That is, $\mathrm{HO}=\mathrm{BX}=0$

\section{Results. A Predictive Model for Satisfaction Degree Based on the KPSS}

Based on the stepwise regression procedure and the goodness of fit of the data for the multiple linear regression model, we observed that the last proposed model (model 5) obtained the highest multiple correlation coefficient $(R)$ (Table 3).

Table 3. Model Summary.

\begin{tabular}{|c|c|c|c|c|c|c|c|c|c|}
\hline \multirow[b]{2}{*}{ Model } & \multirow[b]{2}{*}{$R$} & \multirow{2}{*}{$R$-Square } & \multirow{2}{*}{$\begin{array}{l}R \text {-Square } \\
\text { Adjusted }\end{array}$} & \multirow{2}{*}{$\begin{array}{c}\text { Standard Error } \\
\text { Estimation }\end{array}$} & \multicolumn{5}{|c|}{ Change Statistics } \\
\hline & & & & & $\begin{array}{l}\text { Change in } \\
R \text {-Square }\end{array}$ & $\begin{array}{l}\text { Change } \\
\text { in } F\end{array}$ & gl1 & g12 & $\begin{array}{c}\text { Sig. Change in } \\
F\end{array}$ \\
\hline 1 & $0.956^{\mathrm{a}}$ & 0.913 & 0.912 & 0.150 & 0.913 & 906.774 & 1 & 86 & 0.000 \\
\hline 2 & $0.966^{b}$ & 0.932 & 0.931 & 0.133 & 0.019 & 23.910 & 1 & 85 & 0.000 \\
\hline 3 & $0.968^{c}$ & 0.938 & 0.936 & 0.128 & 0.006 & 7.463 & 1 & 84 & 0.008 \\
\hline 4 & $0.970^{\mathrm{d}}$ & 0.941 & 0.939 & 0.126 & 0.003 & 4.900 & 1 & 83 & 0.030 \\
\hline
\end{tabular}

Source: prepared by the authors.

This way, on the one hand, it was confirmed that «AS» $(t=13.348 ; p<0.05)$, «STS» $(t=-5.198$; $p<0.05)$, «PSS» $(t=2.449 ; p<0.05)$, and «CTS» $(t=0.229 ; p<0.05)$ explained the independent variable «SAT_GEN» more intensely by means of a positive linear association. On the other hand, we observed that «NS» $(t=-0.190 ; p<0.05)$ explained the independent variable «SAT_GEN» more intensely by means of a negative linear association. Also, the coefficient of determination $\left(R^{2}\right)$ indicated that the variability explained by the model was $94.8 \%$, which is very close to the adjusted coefficient of determination.

Based on the analysis of variance, we performed an ANOVA test (Table 4) and observed that, in model 5 (the one that integrated these five KPSS), the $p$-value associated with the $F$-statistic was lower 
than the level of significance. Therefore, $H_{0}$ was rejected: KPSS («AS»; «STS»; «PSS»; «NS»; «CTS») did not affect the degree of «SAT_GEN».

Table 4. ANOVA ${ }^{\mathrm{a}}$.

\begin{tabular}{|c|c|c|c|c|c|c|}
\hline & Model & Sum of Squares & gl & Root Mean Square & $F$ & Sig. \\
\hline \multirow{4}{*}{1} & Regression & 20.385 & 1 & 20.385 & 906.774 & $0.000^{b}$ \\
\hline & Residual & 1.933 & 86 & 0.022 & & \\
\hline & Total & 22.318 & 87 & & & \\
\hline & Regression & 20.809 & 2 & 10.405 & 586.122 & $0.000^{\mathrm{c}}$ \\
\hline \multirow[t]{3}{*}{2} & Residual & 1.509 & 85 & 0.018 & & \\
\hline & Total & 22.318 & 87 & & & \\
\hline & Regression & 20.932 & 3 & 6.977 & 422.948 & $0.000^{\mathrm{d}}$ \\
\hline \multirow[t]{3}{*}{3} & Residual & 1.386 & 84 & 0.016 & & \\
\hline & Total & 22.318 & 87 & & & \\
\hline & Regression & 21.010 & 4 & 5.252 & 333.166 & $0.000^{\mathrm{e}}$ \\
\hline \multirow[t]{3}{*}{4} & Residual & 1.309 & 83 & 0.016 & & \\
\hline & Total & 22.318 & 87 & & & \\
\hline & Regression & 21.159 & 5 & 04.232 & 299.442 & $0.000^{f}$ \\
\hline \multirow[t]{2}{*}{5} & Residual & 1.159 & 82 & 0.014 & & \\
\hline & Total & 22.318 & 87 & & & \\
\hline \multicolumn{7}{|c|}{ Note. Sig. = significance } \\
\hline \multicolumn{7}{|c|}{ a. Dependent variable: «SAT_GEN» } \\
\hline \multicolumn{7}{|c|}{ b. Predictors: (Constant), AS } \\
\hline \multicolumn{7}{|c|}{ c. Predictors: (Constant), AS, STS } \\
\hline \multicolumn{7}{|c|}{ d. Predictors: (Constant), AS, STS, PSS } \\
\hline \multicolumn{7}{|c|}{ e. Predictors: (Constant), AS, STS, PSS, NS } \\
\hline \multicolumn{7}{|c|}{ f. Predictors: (Constant), AS, STS, PSS, NS, CTS } \\
\hline
\end{tabular}

Source: prepared by the authors.

Therefore, the predictive variables that became part of the equation were «AS», «STS», «PSS», «NS», and «CTS» (Table 5).

In this case we corroborated that the students acquired the competence of anticipation because the game allows the study of different hypothetical scenarios in the medium and long term. The students acquired the competence of systemic thinking because the serious game offered them a complex system of decision-making based on economic, social, and environmental situations. On the other hand, problem solving was positively satisfied because the game offers different cases according to the level of difficulty. Finally, future graduates were forced to make responsible decisions regarding sustainability from a tactical point of view while questioning their decisions, thereby developing critical thinking.

The excluded KPSS were «SS» $(t=-1.509 ; p>0.05)$, «SAS» $(t=0.986 ; p>0.05)$, and «CS» $(t=1.925$; $p>0.05$ ) (Table 6): SAT_GEN $=-1.176+0.925 \cdot A S+0.2176 \cdot S T S+0.112 \cdot P S S-0.136 \cdot N S+0,112 \cdot C T S$.

The results of the table obtained through this study show that serious games do not favor the implementation of SS, SAS, and CS skills in the sustainable curricula of students. This is because the methodology used throughout the game encourages competitiveness by producing a final ranking of the scores obtained based on individual decision-making. Therefore, the students do not collectively develop sustainability competencies and thus do not perceive that they are developing strategic skills. Furthermore, this methodology favors work performed in watertight groups without being able to generate between-group feed-back, so the collaborative skill was also not determined to be developed through the game of The Island. Finally, the e-learning methodology used did not give space for the reflection of each individual in relation to the group, thus neglecting the self-awareness skill. 
Table 5. Coefficients ${ }^{\mathrm{a}}$.

\begin{tabular}{|c|c|c|c|c|c|c|}
\hline \multirow{2}{*}{\multicolumn{2}{|c|}{ Model }} & \multicolumn{2}{|c|}{ Non-Standardized Coefficients } & \multirow{2}{*}{$\begin{array}{c}\text { Standardized Coefficients } \\
\text { Beta }\end{array}$} & \multirow[t]{2}{*}{$t$} & \multirow[t]{2}{*}{ Sig. } \\
\hline & & B & Standard Error & & & \\
\hline \multirow{3}{*}{1} & (Constant) & -0.167 & 0.149 & & -1.118 & 0.267 \\
\hline & AS & 1.033 & 0.034 & 0.956 & 30.113 & 0.000 \\
\hline & (Constant) & -1.061 & 0.226 & & -4.698 & 0.000 \\
\hline \multirow[t]{3}{*}{2} & AS & 1.094 & 0.033 & 1.012 & 33.233 & 0.000 \\
\hline & STS & 0.146 & 0.030 & 0.149 & 4.890 & 0.000 \\
\hline & (Constant) & -1.286 & 0.233 & & -5.525 & 0.000 \\
\hline \multirow{3}{*}{3} & SAS & 0.950 & 0.062 & 0.879 & 15.439 & 0.000 \\
\hline & STS & 0.219 & 0.039 & 0.223 & 5.583 & 0.000 \\
\hline & PSS & 0.131 & 0.048 & 0.190 & 2.732 & 0.008 \\
\hline \multirow{5}{*}{4} & (Constant) & -1.098 & 0.243 & & -4.521 & 0.000 \\
\hline & AS & 1.016 & 0.067 & 0.939 & 15.145 & 0.000 \\
\hline & STS & 0.179 & 0.042 & 0.182 & 4.234 & 0.000 \\
\hline & PSS & 0.145 & 0.047 & 0.211 & 3.069 & 0.003 \\
\hline & NS & -0.085 & 0.039 & -0.119 & -2.214 & 0.030 \\
\hline \multirow{6}{*}{5} & (Constant) & -1.176 & 0.231 & & -5.088 & 0.000 \\
\hline & AS & 0.925 & 0.069 & 0.856 & 13.348 & 0.000 \\
\hline & STS & 0.217 & 0.042 & 0.220 & 5.198 & 0.000 \\
\hline & PRA & 0.112 & 0.046 & 0.163 & 2.449 & 0.016 \\
\hline & NS & -0.136 & 0.040 & -0.190 & -3.427 & 0.001 \\
\hline & CTS & 0.159 & 0.049 & 0.229 & 3.254 & 0.002 \\
\hline $\begin{array}{l}\text { Not } \\
\text { a. I }\end{array}$ & $\begin{array}{l}\text { g. = significan } \\
\text { ndent variable }\end{array}$ & AT_GEN & & & & \\
\hline
\end{tabular}

Source: prepared by the authors.

Table 6. Excluded variables ${ }^{a}$.

\begin{tabular}{|c|c|c|c|c|c|c|}
\hline \multirow{2}{*}{\multicolumn{2}{|c|}{ Model }} & \multirow{2}{*}{ Beta } & \multirow[t]{2}{*}{$t$} & \multirow{2}{*}{ Sig. } & \multirow{2}{*}{ Partial Correlation } & \multirow{2}{*}{$\begin{array}{c}\text { Co-Linearity Statistics } \\
\text { Tolerance }\end{array}$} \\
\hline & & & & & & \\
\hline \multirow{8}{*}{1} & PSS & $-0.073^{b}$ & -1.221 & 0.225 & -0.131 & 0.282 \\
\hline & SS & $-0.147^{\mathrm{b}}$ & -2.234 & 0.028 & -0.236 & 0.221 \\
\hline & STS & $0.149^{b}$ & 4.890 & 0.000 & 0.469 & 0.858 \\
\hline & SAS & $0.032^{b}$ & 0.223 & 0.824 & 0.024 & 0.051 \\
\hline & $\mathrm{CS}$ & $-0.034^{b}$ & -1.004 & 0.318 & -0.108 & 0.902 \\
\hline & CTS & $-0.070^{b}$ & -1.175 & 0.243 & -0.126 & 0.282 \\
\hline & NS & $-0.195^{b}$ & -4.181 & 0.000 & -0.413 & 0.388 \\
\hline & PSS & $0.190^{c}$ & 2.732 & 0.008 & 0.286 & 0.153 \\
\hline \multirow{5}{*}{2} & SS & $-0.108^{c}$ & -1.814 & 0.073 & -0.194 & 0.217 \\
\hline & STS & $-0.045^{c}$ & -0.358 & 0.721 & -0.039 & 0.050 \\
\hline & SAS & $0.069^{c}$ & 1.957 & 0.054 & 0.209 & 0.622 \\
\hline & CS & $0.172^{c}$ & 2.538 & 0.013 & 0.267 & 0.162 \\
\hline & CTS & $-0.097^{c}$ & -1.730 & 0.087 & -0.185 & 0.248 \\
\hline \multirow{5}{*}{3} & SS & $-0.114^{\mathrm{d}}$ & -1.991 & 0.050 & -0.214 & 0.217 \\
\hline & SAS & $0.000^{\mathrm{d}}$ & 0.000 & 1.000 & 0.000 & 0.049 \\
\hline & $\mathrm{CS}$ & $0.048^{\mathrm{d}}$ & 1.351 & 0.180 & 0.147 & 0.581 \\
\hline & CTS & $0.134^{\mathrm{d}}$ & 1.954 & 0.054 & 0.210 & 0.152 \\
\hline & NS & $-0.119^{\mathrm{d}}$ & -2.214 & 0.030 & -0.236 & 0.243 \\
\hline \multirow{4}{*}{4} & SS & $-0.106^{\mathrm{e}}$ & -1.880 & 0.064 & -0.203 & 0.216 \\
\hline & SAS & $0.170^{\mathrm{e}}$ & 1.241 & 0.218 & 0.136 & 0.037 \\
\hline & CS & $0.083^{\mathrm{e}}$ & 2.310 & 0.023 & 0.247 & 0.516 \\
\hline & CTS & $0.229^{e}$ & 3.254 & 0.002 & 0.338 & 0.128 \\
\hline \multirow{3}{*}{5} & SS & $-0.082^{f}$ & -1.509 & 0.135 & -0.165 & 0.211 \\
\hline & SAS & $0.129^{f}$ & 0.986 & 0.327 & 0.109 & 0.037 \\
\hline & $\mathrm{CS}$ & $0.067^{f}$ & 1.925 & 0.058 & 0.209 & 0.503 \\
\hline $\begin{array}{l}\text { Note } \\
\text { a. } \mathrm{D} \\
\text { b. } \mathrm{Pr} \\
\text { c. } \mathrm{Pr} \\
\text { d. } \mathrm{Pr} \\
\text { e. } \mathrm{Pr} \\
\text { f. Pr }\end{array}$ & $\begin{array}{l}=\text { sig } \\
\text { ident } \\
\text { tors in } \\
\text { tors in } \\
\text { tors in } \\
\text { tors in } \\
\text { tors in }\end{array}$ & $\begin{array}{l}\text { ficance } \\
\text { riable: SA } \\
\text { he model: } \\
\text { he model: } \\
\text { he model: } \\
\text { ne model: } \\
\text { he model: }\end{array}$ & $\begin{array}{l}\text { GEN } \\
\text { Constant } \\
\text { Constant } \\
\text { Constan } \\
\text { Constant } \\
\text { Constant }\end{array}$ & $\begin{array}{l}\text {, STS } \\
\text {, STS, } \\
\text {, STS, I } \\
\text {, STS, I }\end{array}$ & $\begin{array}{l}\text { IS } \\
\text { S, CTS }\end{array}$ & \\
\hline
\end{tabular}




\section{Discussion and Conclusions}

SG should be used in universities as a tool for ESD. Several studies have indicated that SG favors active student learning [6,50-52].

Likewise, the potential of SG in the curricular sustainability of KPSS through the SDG has been confirmed because most of competencies are developed through simulations that achieve optimal citizen education, as defined in the Agenda for $2030[3,18,53]$.

The objective of this work was to analyze which KPSS are developed through The Island, in order to improve the degree of satisfaction of students in the incorporation of a sustainable curriculum and thus to confirm the potential of SG as an e-learning tool. Therefore, to develop sustainable skills among university students, we can conclude that SG develop sustainable competences differently. The most developed competencies are as follows: The competence of anticipation, since the students, thanks to the simulator, analyzed and evaluated different future scenarios; the competence of systemic thinking, since the students recognized and understood their relationship with society, thereby analyzing a complex system; the integrated competence of problem solving, because the future graduates applied different frameworks of problem solving to the different situations posed by the serious game; and finally, critical thinking, which offers the possibility to question practices and opinions, make conscious decisions, and act responsibly in the present without losing sight of the economic, social, and environmental sustainability of the future.

The normative competence scores were negative, since the students felt that the rules of the SG were previously established and unchangeable, with no room for reflection or change, since simulation games are a mental test according to specific rules.

The following competences were excluded, as The Island is an activity that was carried out in a competitive way, where the most important goal was to win: 1) Strategic competence, as the students could not collectively develop sustainability actions; 2) collaborative competence, as the simulator was developed for groups of students, not teams, so the students did not learn from each other and thus could not develop empathic leadership; 3 ) self-awareness, as this game did not present the student with the option to reflect on his or her individual role in the community, or to analyze what actions were developed by that role.

On the one hand, the implications of this study are pedagogical (i.e., the results can help develop methodologies for teaching-learning). The results are also applicable to management, such as developing KPSS that will allow students to face the challenges in decision making in the organizations where they will work, thereby developing skills today to act tomorrow from a sustainable perspective based on the Triple Bottom Line.

The serious game called "The Island", implemented as an active methodology for e-learning, supports sustainable curricula through the development of KPSS among students of higher education. In this way, future graduates can become agents of change and contribute to the development of the SDG of Agenda 2030. The university, as an agent of change, must take an active role based on the pillars of the ESD defined by UNESCO. Learning to understand, act, and live together will facilitate a type of education in which all students are responsible and sustainable citizens capable of making economic, social, and environmental decisions, in both their personal and professional lives, thereby promoting a better world for all.

\section{Limitations}

This study focused on a single geographical region (Bizkaia) and on only one area of knowledge: business management. Moreover, only one serious game was analyzed: The Island.

\section{Future Projects}

Due to the ease of extrapolation, it would be interesting to extend this study to different geographical areas, both national and international. It would also be interesting to extrapolate it to 
other educational levels and fields of knowledge, such as the Sciences and Humanities. Another project would be to analyze The Island through an active collaborative methodology, in order to favor the achievement of competences excluded from this study, such as strategy, collaborative, and self-awareness skills.

Author Contributions: N.P.M. analyzed and wrote the introduction, state of play and designed the study. J.C.L. analyzed the data and wrote the Materials and Methods. A.M.G. wrote the results section. J.C.L.and A.M.G. collected the data. All authors contributed to manuscript revision and proofreading and approved the submitted version of the manuscript.

Funding: We are grateful for the financial support received from the University of the Basque Country under Grant Consolidated Research Group EJ/ GV: IT 897-16 and Campus Bizi Lab 19Peña

Conflicts of Interest: The authors declare no conflict of interest

\section{Appendix A}

Preliminary analysis on the development of competencies for education for sustainable development through active methodology and simulation games

Gender

\section{Man}

Woman

Non-binary

Where are you currently studying?

$\bigcirc \quad$ Degree in Business Management (UBS)

$\bigcirc$ or MACS (UPV/EHU)

$\bigcirc \quad$ or PRT (UPV/EHU)

Throughout your university life in how many subjects have you used a business simulator/game?

$$
\begin{array}{ll}
\bigcirc & 0 \\
\bigcirc & 1 \\
\bigcirc & 2 \\
\bigcirc & 3 \\
\bigcirc & \text { More than } 3
\end{array}
$$

Throughout your university life, in how many subjects have you received specific training on sustainability (may be from the economic, social, political and/or environmental dimension)?

$$
\begin{array}{ll}
\bigcirc & 0 \\
\bigcirc & 1 \\
\bigcirc & 2 \\
\bigcirc & 3 \\
\bigcirc & \text { More than } 3
\end{array}
$$

Key professional skills for sustainability: What is the level of KPSS you have acquired so far in terms of incorporating these competencies into your sustainability curriculum? Answer by assuming that 1 is "none" and 5 "many". 


\begin{tabular}{|c|c|c|c|c|c|}
\hline & NONE & LITTLE & MEDIUM & ENOUGH & VERY MUCH \\
\hline \multicolumn{6}{|l|}{$\begin{array}{l}\text { Systems thinking skill: the skills to recognize and } \\
\text { understand relationships; to analyze complex systems; } \\
\text { to think about how systems are integrated within } \\
\text { different domains and scales; and to deal } \\
\text { with uncertainty }\end{array}$} \\
\hline \multicolumn{6}{|l|}{$\begin{array}{l}\text { Anticipatory skill: the skills to understand and } \\
\text { evaluate multiple future scenarios - the possible, the } \\
\text { probable and the desirable; to create one's own vision } \\
\text { of the future; to apply the precautionary principle; to } \\
\text { evaluate the consequences of actions; and to deal with } \\
\text { risks and change }\end{array}$} \\
\hline \multicolumn{6}{|l|}{$\begin{array}{l}\text { Regulatory skill: the skills to understand and reflect on } \\
\text { the norms and values underlying our actions; and to } \\
\text { negotiate sustainability values, principles, objectives } \\
\text { and targets in a context of conflicts of interest and } \\
\text { trade-offs, uncertain knowledge and contradictions } \\
\text { Strategic skill: the skills to collectively develop and } \\
\text { implement innovative actions that promote } \\
\text { sustainability at the local level and beyond }\end{array}$} \\
\hline \multicolumn{6}{|l|}{$\begin{array}{l}\text { Collaborative skill: the skills to learn from others; to } \\
\text { understand and respect the needs, perspectives and } \\
\text { actions of others (empathy); to understand, identify } \\
\text { with and be sensitive to others (empathetic leadership); } \\
\text { to address group conflict; and to facilitate collaborative } \\
\text { and participatory problem solving }\end{array}$} \\
\hline \multicolumn{6}{|l|}{$\begin{array}{l}\text { Critical thinking skill: the ability to question norms, } \\
\text { practices and opinions; to reflect on one's values, } \\
\text { perceptions and actions; and to take a stand in the } \\
\text { sustainability discourse }\end{array}$} \\
\hline \multicolumn{6}{|l|}{$\begin{array}{l}\text { Self-awareness skill: the ability to reflect on one's role } \\
\text { in the local community and society (worldwide); to } \\
\text { constantly evaluate and encourage one's actions; and } \\
\text { to deal with feelings }\end{array}$} \\
\hline $\begin{array}{l}\text { Integrated problem-solving skill: the overall ability to } \\
\text { apply different problem-solving frameworks to } \\
\text { complex sustainability problems and to devise } \\
\text { equitable solution options that promote sustainable } \\
\text { development, integrating the above competencies }\end{array}$ & & & & & \\
\hline
\end{tabular}

How satisfied are you overall with the university in developing your sustainable curriculum? Answer by assuming that 1 is "none" and 5 "a lot".
1. None
2. Little
2. Medium
4. Enough
5. Very Much

\section{Appendix B}

Further analysis on the development of competencies for education for sustainable development through active methodology and simulation games.

Gender

○ Man

Woman

Non-binary

Where are you currently studying?

$\bigcirc \quad$ Degree in Business Management (UBS) 

or MACS (UPV/EHU)
or PRT (UPV/EHU)

Throughout your university life in how many subjects have you used a business simulator/game?

$\begin{array}{ll}\bigcirc & 0 \\ \bigcirc & 1 \\ \bigcirc & 2 \\ \bigcirc & 3 \\ \bigcirc & \text { More than } 3\end{array}$

Throughout your university life, in how many subjects have you received specific training on sustainability (may be from the economic, social, political and/or environmental dimension)?

$\begin{array}{ll}\bigcirc & 0 \\ \bigcirc & 1 \\ \bigcirc & 2 \\ \bigcirc & 3 \\ \bigcirc & \text { More than } 3\end{array}$

Key professional skills for sustainability: What is the level of KPSS you have acquired after using the SG: The Island? Answer by assuming that 1 is "none" and 5 "many".

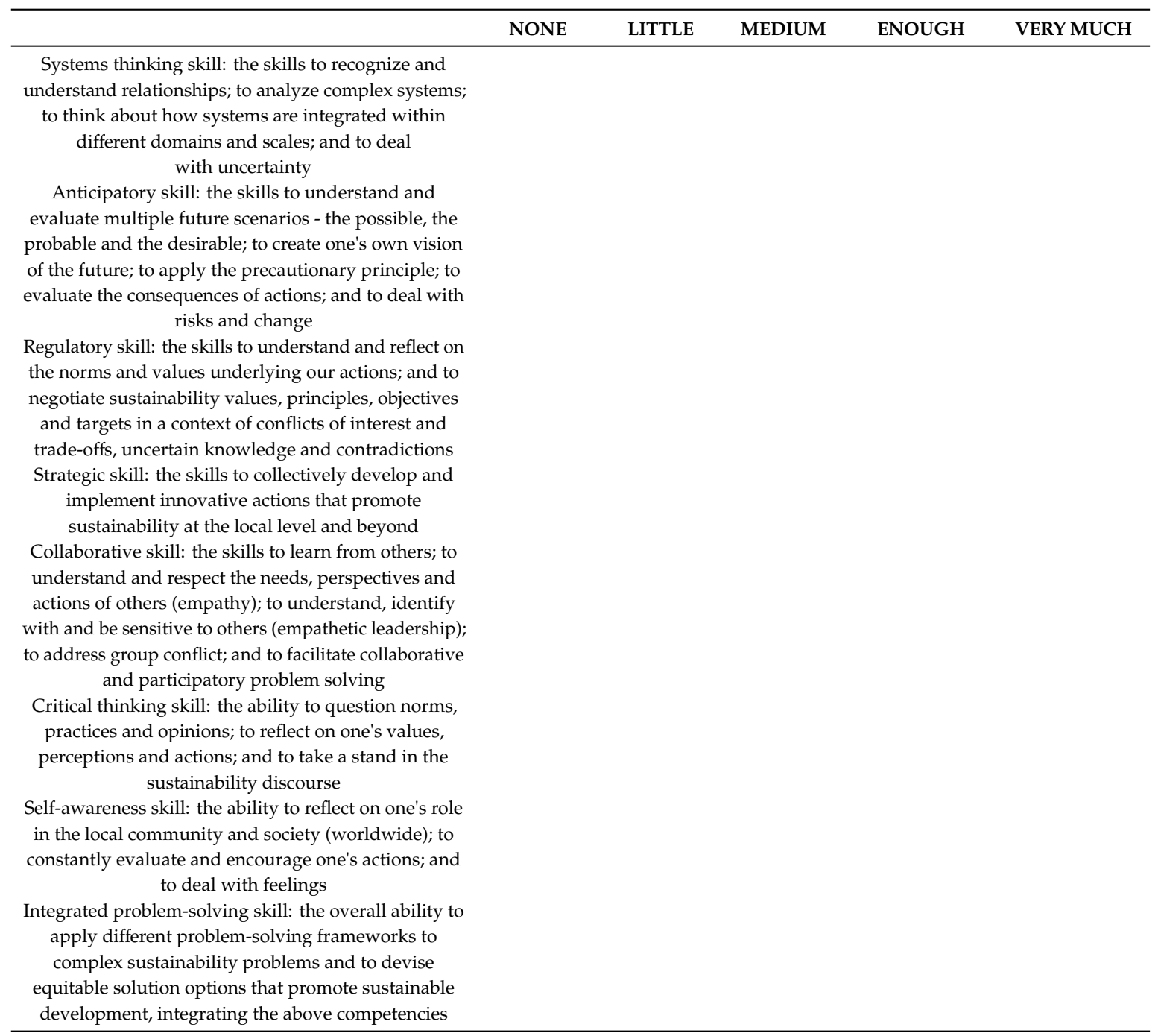


What is your general level of satisfaction with the use of the SG: The Island as a tool to assist in the development of its sustainable curriculum throughout your university career? Answer by assuming that 1 is "none" and 5 "very much".
1. None
2. Little
2. Medium
4. Enough
5. Very Much

\section{References}

1. Sustainability, Global. Global sustainability: the history/time line of an idea. RMIT, Melbourne 2001, 4.

2. Glavic, P.; Lukman, R. Review of sustainability terms and their definitions. J. Clean. Prod. 2007, 15, 1875-1885. [CrossRef]

3. De Haan, G. The development of ESD-related competencies in supportive institutional frameworks. Int. Rev. Educ. 2010, 56, 315-328. [CrossRef]

4. Rychen, D.S. Competencias Clave: Abordar Desafios Importantes En Vida, 1st ed.; Hogrefe y Huber: Cambridge, UK, 2003; pp. 63-107.

5. Weinert, F.E. Concept of competence: A conceptual clarification. In Defining and Selecting Key Competencies, 2nd ed.; Rychen, D.S., Salganik, L.H., Eds.; Hogrefe \& Huber Publishers: Göttingen, Germany, 2001; pp. 45-65.

6. Katsaliaki, K.; Mustafee, N. Edutainment for sustainable development: A survey of games in the field. Simul. Gaming 2015, 46, 647-672. [CrossRef]

7. Macarrón, L.S. La educación ambiental o la educación para el desarrollo sostenible: su interpretación desde la visión sistémica y holística del concepto de medio ambiente. Educ. Y Futuro: Rev. De Investig. Apl. Y Exp. Educ. 2012, 26, 17-42.

8. Rondón, M.R. La Educación ambiental en puerto rico: Propuesta para un modelo interdisciplinario de educación formal. Run. Rev. Científica De Investig. Educ. 2018, 1, 167-184.

9. Edwards, J.; Fogelman, K. Developing citizenship in the curriculu, 1st ed.; Routledge: London, UK, 2018.

10. UNESCO. Education for Sustainable Developments Goals-Learning Objetives, 1st ed.; Organización De Las Naciones Unidas Para La Educación y La Cultura: París, Francia, 2017.

11. Gutiérrez,J.; Benayas, J.; Calvo, S. Educación para el desarrollo sostenible: evaluación de retos y oportunidades del decenio 2005-2014. Rev. Iberoam. De Educ. 2006, 40, 25-60.

12. Weiss, E.B. United Nations conference on environment and development. Int. Leg. Mater. 1992, 31, 814-817. [CrossRef]

13. Bunting, C.; Hunt, J.; Walker, L.; de Roode, J. World summit on sustainable development. Times High. Educ. Suppl. 2002, 1552, 16-19.

14. Naab, D. United Nations Conference on Sustainable Development, 1st ed.; Grin Verlag: Berlin, Germany, 2012.

15. McKeown, R.; Hopkins, C.A.; Rizi, R.; Chrystalbridge, M. Education for Sustainable Development Toolkit, 2nd ed.; Energy, Environment and Resources Center, University of Tennessee: Knoxville, TN, USA, 2002.

16. Martínez, P. La contribución de las universidades al logro de las ODS. In Proceedings of the Congreso de la conferencia iberoamericana sobre objetivos de desarrollo sostenible, Salamanca, Spain, 27-29 June 2018.

17. Cebrián, G.; Junyent, M. Competencies in education for sustainable development: Exploring the student teachers' views. Sustainability 2015, 7, 2768-2786.

18. Kagawa, $\mathrm{F}$. Dissonance in students' perceptions of sustainable development and sustainability: Implications for curriculum change. Int. J. Sustain. High. Educ. 2007, 8, 317-338. [CrossRef]

19. Pyrini, N.; Varonis, O.J.; Varonis, E.M. The open wings project: Transforming students' perceptions of self and society through the development of the homonomous self. Int. J. Inf. Learn. Technol. 2017, 34, 83-101. [CrossRef]

20. UNESCO. Rethinking Education: Towards a Global Common Good? UNESCO: Paris, France, 2015.

21. Prado, A.M.; Arce, R.; Lopez, L.E.; García, J. Simulations versus case studies: effectively teaching the premises of sustainable development in the classroom. J. Bus. Ethics 2020, 161, 303-327. [CrossRef] 
22. Bates, I.Y.; Atkins, D. Management of Insurance Operations, 1st ed.; Institute of Financial Services: London, UK, 2003.

23. Rajan, A.; Van Eupen, P.; Chapple, K. Skills in Financial Services. Insurance, Banking \& Building Societies; Centre For Research In Employment \& Technology: Kent, UK, 1999.

24. Scavone, G.; Fronti de García, L.; Fernández Cuesta, C. Los desafíos de la contabilidad de sustentabilidad. Revista AECA 2019, 125, 7-10.

25. UNESCO. Indicadores Temáticos Para Monitorear La Agenda De Educación 2030, 1st ed.; Instituto Estadístico de la UNESCO: Madrid, Spain, 2015.

26. Aldeanueva, C.M.; Rojo, A.; Pastor, M.; Gurmu, D.; Stott, L.; Mazorra, J. Alianzas multiactor para la innovación social en la consecución de los ODS: la universidad y su gran potencial como facilitador y promotor. Rev. Española De Desarro. Y Coop. 2017, 41, 27-38.

27. Ruiz, M.J.B.C.; González, M.J.D. La sostenibilidad en los grados universitarios: presencia y coherencia. teoría de la educación. Rev. Interuniv. 2017, 29, 161-187.

28. McMillan, J. University Community Engagement and Lifelong Learning: the Porous University, 1st ed.; Palgrave MacMillan: Dourban, South Africa, 2018.

29. Preece, J. Implications of the Porous University for Policy and Practice in University Community Engagement and Lifelong Learning, 1st ed.; Palgrave Macmillan: London, UK, 2017.

30. Stewart, M. The Porous University: Impact is not some added extra of academic life, but lies at the core of what we do. Impact of Social Sciences Blog. Available online: http://eprints.lse.ac.uk/70693/1/blogs.lse.ac.ukThe $\% 20$ Porous $\% 20$ University $\% 20$ Impact $\% 20$ is $\% 20$ not $\% 20$ some $\% 20$ added $\% 20$ extra $\% 20$ of $\% 20$ academic $\%$ 20life $\% 20$ but $\% 20$ lies \%20at\%20the\%20core\%20of\%20what\%20we.pdf (accessed on 5 December 2015).

31. Granados, J.; Junyent, M. Retos y oportunidades en la ambientalización curricular. Cuad. De Pedagog. 2015, 460, 48-52.

32. Pujol, R.M.; Villanueva, M. Un proces metodologic per l'ambientació curricular. Proceedings of seminaris d'ambientalització curricular, Barcelona, España; 1998; pp. 31-43.

33. Wals, A.E. Beyond Unreasonable Doubt. Education and Learning for Socio-Ecological Sustainability in the Anthropocene, 1st ed.; Wageningen University: Wageningen, The Netherlands, 2015.

34. Wals, A.E.; Lenglet, F. Sustainability citizens: collaborative and disruptive social learning. In Sustainability Citizenship in Cities, 1st ed.; Routledge: UK, London, 2016; pp. 72-86.

35. Larrán, M.; Andrades, J.; Herrera, J. An examination of attitudes and perceptions of Spanish business and accounting students toward corporate social responsibility and sustainability themes. Rev. De Contab. 2018, 21, 196-205. [CrossRef]

36. Barr, S. Environment and society: Sustainability, policy and the citizen, 1st ed.; Routledge: London, UK, 2016.

37. Carter, N. The Politics of the Environment: Ideas, Activism, Policy, 1st ed.; University Press: Cambridge, UK, 2018.

38. Knox, P.L.; Marston, S.A.; Imort, M. Human Geography: Places and Regions in Global Context, 1st ed.; Pearson: London, UK, 2016.

39. Wiek, A.; Withycombe, L.; Redman, C.L. Key competencies in sustainability: a reference framework for academic program development. Sustain. Sci. 2011, 6, 203-218. [CrossRef]

40. Macías, A.C.; Cañedo, T.J.; Eudave, D.; Páez, D.A.; Carvajal, M. Argumentación del tutor de educación superior sobre su práctica y experiencia en el contexto del trabajo colaborativo. Investig. Cual. En Educ. 2017, 1, 791-799.

41. Marín-García, J.A.; Maheut, J.; García-Sabater, J.J. Analisis del grado de consistencia entre diferentes modos de evaluar las competencias transversales de creatividad, pensamiento crítico, liderazgo y trabajo en equipo/red. Proceedings of IN-RED 2017: III Congreso nacional de innovación educativa y docencia en red, Valencia, Spain, 13-14 July 2017.

42. Alles, M. Elija Al Mejor: La Entrevista En Selección De Personal. La Entrevista Por Competencias, 3rd ed.; Ediciones Granica: Madrid, España, 2019.

43. Rieckmann, M. Future-oriented higher education: Which key competencies should be fostered through university teaching and learning? Futures 2012, 44, 127-135. [CrossRef]

44. Goldin, C.; Katz, L.F. The Race between Education and Technology. In Inequality in the 21st Century, 1st ed.; Routledge: London, UK, 2018; pp. 49-54. 
45. Breuer, J.; Bente, G. Why so serious? On the relation of serious games and learning. J. Comput. Game Cult. 2010, 4, 7-24.

46. Corrigan, S.; Zon, G.D.R.; Maij, A.; McDonald, N.; Mårtensson, L. An approach to collaborative learning and the serious game development. Cogn. Technol. Work 2015, 17, 269-278. [CrossRef]

47. Katsaliaki, K. Serious games for sustainable development. J. Manag. Educ. 2013, 37, 889-894. [CrossRef]

48. Adomssent, M.; Godemann, J.; Michelsen, G.; Barth, M.; Rieckmann, M.; Stoltenberg, U. Developing key competencies for sustainable development in higher education. Int. J. Sustain. High. Educ. 2007, 8, 416-430.

49. Murga-Menoyo, M.Á. Competencias para el desarrollo sostenible: las capacidades, actitudes y valores meta de la educación en el marco de la Agenda global post-2015. De Educ. 2015, 13, 55-83.

50. Calabor, M.S.; Mora, A.; Moya, S. Adquisición de competencias a través de juegos serios en el área contable: un análisis empírico. Span. Account. Rev. 2018, 21, 38-47. [CrossRef]

51. Liarakou, G.; Sakka, E.; Gavrilakis, C.; Tsolakidis, C. Evaluation of serious games, as a tool for education for sustainable development. Eur. J. Opendistance E-Learn. 2012, 15, 96-110.

52. Thirouard, M.; Bernaert, O.; Dhorne, L.; Bianchi, S.; Pidol, L.; Petit, Y. Learning by doing: integrating a serious game in a MOOC to promote new skills. In Proceedings of the European MOOC stakeholder summit 2015, Graz, Austria, 18-20 May 2015; pp. 92-96.

53. Willemse, T.M.; Ten Dam, G.; Geijsel, F.; Van Wessum, L.; Volman, M. Fostering teachers' professional development for citizenship education. Teach. Teach. Educ. 2015, 49, 118-127. [CrossRef]

(C) 2020 by the authors. Licensee MDPI, Basel, Switzerland. This article is an open access article distributed under the terms and conditions of the Creative Commons Attribution (CC BY) license (http://creativecommons.org/licenses/by/4.0/). 